\title{
Morphological studies and development of ex-situ protocol for rehabilitation of threatened Rheum species under nursery conditions
}

\author{
Shagoon Tabin ${ }^{1 *}$, Azra N. Kamili', R. C. Gupta ${ }^{2}$ \\ ${ }^{1}$ Centre of Research for Development, University of Kashmir, Srinagar, Jammu and Kashmir, India, \\ ${ }^{2}$ Department of Botany, Punjabi University, Patiala, Punjab, India
}

\author{
Received: 26.03.2016 \\ Accepted: 07.05.2016 \\ Published: 20.05.2016 \\ *Address for \\ correspondence: \\ Shagoon Tabin, Centre of \\ Research for Development, \\ University of Kashmir, \\ Srinagar, Jammu and \\ Kashmir, India. E-mail: \\ shagoonkhan@gmail.com
}

\begin{abstract}
Rheum is a strong vigorous plant and can live long even in tough conditions. The Rheum species have been domesticated as medicinal plants for human consumption. Rheum species are perennial stout herbs. Rhubarb is a common English name of the genus Rheum. Rhubarb is a plant name for the many different species of Rheum, distributed in the temperate and sub-tropical regions of Himalaya from Kashmir to Sikkim and growing wild in the mountains of the Western and North-western provinces of China and adjoining Tibetan territory. It is cultivated much in Europe and the United States. In Kashmir Himalaya, it ranges from an altitude of $1700-5500 \mathrm{~m}$. It is famous for its medicinal uses. Roots are long and stout. The stem is erect, hollow, sulcate, glabrous, or strigose. It is native to Asia-Temperate to Asia-Tropical, from China to India, Nepal, and Pakistan. In India, its found in Himachal Pradesh, Jammu and Kashmir, and Uttar Pradesh. In Jammu and Kashmir, it grows on open slopes and shrubberies in Kashmir, Leh and Zanaskar valley between 3000 and $5000 \mathrm{~m}$, where Rheum webbianum is found. The Rheum spiciforme is also one of the most known medicinal plant and is found on high altitudes of Gurez valley $(3000 \mathrm{~m}, 5000 \mathrm{~m})$. Rheum also prefers a full sunny location and thrives in a moist, fertile soil. Most Rheum species can handle heavier clay soils better than many other herbs and makes a striking addition to the spring landscape. Rhubarb is propagated from seeds, seedlings, or pieces of rhizome.
\end{abstract}

KEY WORDS: Gurez, medicinal plant, Kashmir Himalaya, Leh, Rheum spiciforme, Rheum webbianum, Rhubarab, Zanaskar

\section{INTRODUCTION}

The medicinal properties of plant species have made an outstanding contribution in the origin and evolution of many traditional herbal therapies. These traditional knowledge systems have started to disappear with the passage of time due to the scarcity of written documents and relatively low income in these traditions. Over the past few years, however, the medicinal plants have regained a wide recognition due to an escalating faith in herbal medicine in view of its lesser side effects compared to allopathic medicine, in addition, the necessity of meeting the requirements of medicine for an increasing human population. Many compounds used in today's medicine have a complex structure, and synthesizing these bioactive compounds chemically at a low price is not easy (Shimomura et al., 1997). With deforestation, medicinal wealth is rapidly lost, such that many valuable plants are threatened with extinction. Medicinal plants have been the subjects of man's interest since time immemorial and play a key role in human health (Constabel, 1990). Medicinal plants have been identified and used throughout human history. Almost every civilization has a history of medicinal plant use (Ensminger et al., 1983). The association of humans with plants obviously originated with the beginning of life on earth when plants provided the oxygen, food, forage, shelter, and medicine needed for higher life forms.

The Valley of Kashmir known for its beauty all over the world is also rich in herbal and floral wealth. The valley of Kashmir is very rich in high value and high altitude aromatic and medicinal plants. Kashmir valley has a great potential for establishing pharmaceutical and essential oil industry based on these high-value plant species. Prominent among the aroma bearing plants 
are Lavender, Rose, Clarysage, Peppermint, Rosemary, Artemisia annua, Tagetes minuta, and Geranium oils. The essential oils derived from these plants form the backbone of perfumery, cosmetic industry. These oils rank among the top 10 essential oils used in aromatherapy throughout the world. The medicinal properties of various herbs and flowers growing in Kashmir need to be publicized so that the local inhabitants particularly villages would not let these plants fall in waste due to lack of awareness.

Rheum species is a perennial stout herb. Rhubarb is the English name of the genus Rheum (family Polygonaceae). There are about 60 species of the genus Rheum recorded in the world (Agarwal et al., 2001). Rhubarb is a plant name for the many different species of Rheum, distributed in the temperature and sub-tropical regions of Himalaya from Kashmir to Sikkim (Nautiyal et al., 2003) and growing in the wild in the mountains of the Western and Northwestern provinces of China and in the adjoining Tibetan territory and in cultivation in much of Europe and the United States. In Kashmir Himalaya ranges from an altitude of 1700-5500 m. It is famous for its Medicinal uses.

Rheum emodi is a perennial plant that grows from thick short and erected rhizomes. The large, somewhat triangular leaf blades are elevated on long, fleshy petioles. The flowers are small, greenish-white, and borne in large compound leafy inflorescences. It is a leafy perennial herb, streaked green, radical leaves, orbicular or broadly ovate, cordate at base, often long, 5-7 nerved papilose beneath. Petiole long and stout. Inflorescence panicles, flower dark purple, sepals 5, stamens 6-9, overy 2-4, fruit long, ovoid-oblong, purple. This family of plants contains at least 40 genera and more than 800 species, all with jointed stems. Other characters include leaf stipules: United into a tubular sheath called an ocrea; sepals: Petaloid; petals: Absent; fruit: An achene. R. emodi, commonly known as Himalayan rhubarb, is a medicinal herb used in the Indian Ayurvedic system of medicine. Rhubarbs are large perennial herbs. The flower stalk is solid or hollow and reaches a height of 1.5-2 m. The radical leaves, which have long, succulent petioles, form a rosette and are very large and usually entire. Rhubarb is propagated from seeds, seedlings, or pieces of rhizome.

Rheum webbianum Royle is an important medicinal plant belonging to the family Polygonaceae. It is commonly known as "Himalayan Rhubarb" in English, "Ravanchini" in Hindi, "Xu Mi Da Huang” in Chinese, "Chotal” in Pakistan and "Lachhu" or "Chu-rtsa" in Ladakh. It is native to AsiaTemperate to Asia-Tropical, from China to India, Nepal and Pakistan. In India, it is found in Himachal Pradesh,
Jammu and Kashmir, Uttar Pradesh. In Jammu and Kashmir, it is grown on open slopes and shrubberies in Kashmir, Leh and Zansker valley (Chaurasia et al., 2007). It can be identified having basal and cauline leaves. Basal leaves are orbicular or broadly ovate, large, 30-60 cm long, abaxially pubescent, adaxially papilliferous or muricate, basal veins 5 , base subcordate, deeply palmately 5 -lobed, middle 3 lobes pinnatisect, apex narrowly acute. Stem leaves are few and smaller than the basal ones. Ocrea is large, membrane, entire and brown. Panicle is large. The pedicels are articulate. The tepals are six, white, purplered, rarely light red, and orbicular. The stamens are 9 . The ovary is broadly ovoid, 1-locular, and 1-ovule. The styles are three, horizontal in axis. It is perennial and 1.5-2 (occasionally up to 2.5 ) $\mathrm{m}$ tall. The root is stout, straight, up to $30 \mathrm{~cm}$ in length, up to $10 \mathrm{~cm}$ in diameter and dark brown outside and yellow or red-yellow inside in color. The stem is stout, hollow, finely sulcate, and glabrous or pubescent. The species have large somewhat triangular shaped leaves with long, fleshy petioles. The flowers are small, greenish-white to rose-red, and grouped in large compound leafy inflorescences.

Rheum spiciforme is also the stout herbs. Petiole of basal leaf purplish red, subterete, $3-10 \mathrm{~cm}$, stout, glabrous or papilliferous; leaf blade purple-red abaxially, dark green or yellow-green adaxially, ovate or broadly ovateelliptic, nearly leathery, both surfaces papilliferous or abaxially glabrous, basal veins 5 , base rounded or subcordate, margin entire and slightly sinuolate, apex obtuse. Leaves all radical, petiole 7-15 cm long, very hard, usually glabrous, blade very leathery, orbicular, broadly ovate or cordate, nerves prominently radiating, red-brown; 15-30 cm long and broad, glabrous or slightly stellate hairy below. Inflorescence pedunculate, glabrous, 10-30 cm long spike-like raceme. Flowers small, 2-3 $\mathrm{mm}$ across, pedicel 2-7 $\mathrm{mm}$ long; bracteate, bract minute, ovate, scarious. Perianth segments small, entire, obtuse, 2-3 mm long, yellowish or somewhat reddish. Fruit broadly ellipsoid or oblong, 0.5-1.5 cm long, rounded at the apex; wings membranous, broader than the disk.

Other species of Rheum found in the different parts of world are Rheum rhabarbarum, Rheum hotaoense, Rheum wittrockii, Rheum altaicum, Rheum forrestii, Rheum likiangense, Rheum lhasaense, Rheum compactum, Rheum glabricaule, Rheum officinale, Rheum palmatum, Rheum tanguticum, Rheum laciniatum, Rheum acuminatum, Rheum maculatum, Rheum yunnanense, Rheum kialense, Rheum racemiferum, Rheum sublanceolatum, Rheum inopinatum, Rheum pumilum. Rheum delavayi, Rheum subacaule, Rheum uninerve, Rheum nanum, 
Rheum tibeticum, Rheum tataricum, Rheum moorcroftianum, Rheum przewalskyi, Rheum rhizostachyum, Rheum reticulatum, Rheum globulosum, Rheum nobile, Rheum alexandrae, R. acuminatum, Rheum alpinum, R. altaicum, Rheum coreanum, Rheum $x$ hybridum, and Rheum ribes.

\section{MATERIALS AND METHODS}

\section{Surveys and Ex-situ Conservation}

Surveys were done for the collection of three species of Rheum from high altitudes of Kashmir Himalaya. R. emodi was collected from various altitudes such as Yousmarg, Dodhpathri, Thajwas Glacier (Sonmarg), Affarwat (Gulmarg), Dagvan (Tarsar Marsar), Aaroo (Pahalgaam), Laar, and Dhara. R. webbianum was collected from ladakh region, i.e., Tangsti, Khardungla, Panzila Top (Zanaskar), Tangole (Zanaskar), and Parakhachik (Zanaskar). R. spiciforme was collected from Gurez area, i.e., Dawar hills, Dahi Nala, Chakwali, Habbakhatoon Mountain, and Tragbal. All the study sites are depicted in Figure 1 and Table 1 . The specimens were identified by consulting the Flora of China (Shu et al. 2003) and Alpine Flora of Kashmir Himalaya (Dhar and Kachroo 1983). Further, the confirmation of the specimens was done by comparing the specimens in the Herbarium, Department of Botany, University of Kashmir, Kashmir and Punjabi University, Patiala and the authenticated voucher numbers have been obtained from both the universities.

\section{Growth in Nursery}

The seeds, roots, rhizomes, and whole plants collected from different locations were planted under natural, shady and suitable environmental conditions in the beds of net house at Naseem Bagh Campus of University of Kashmir, Srinagar. Each bed had its own name plate mentioning the place and date of collection. The plants were monitored on daily basis for their growth responses.

Rheum is also called cliff hanger as it grows on rocks and at high altitude from 2000 to $6000 \mathrm{~m}$, so it needs suitable and favorable conditions when grown ex-situ. So far, for the establishment of Rheum species in the nursery, the soil was also taken from high altitudes along with the plant which was mixed with the soil of net house. Different soil texture groups were also used with or without fertilizer urea.

\section{Studies of Morphological Features}

Morphological traits cover the root length, root thickness, rhizome length, rhizome thickness, leaf length, leaf breadth, leaf number, number of branches, number of

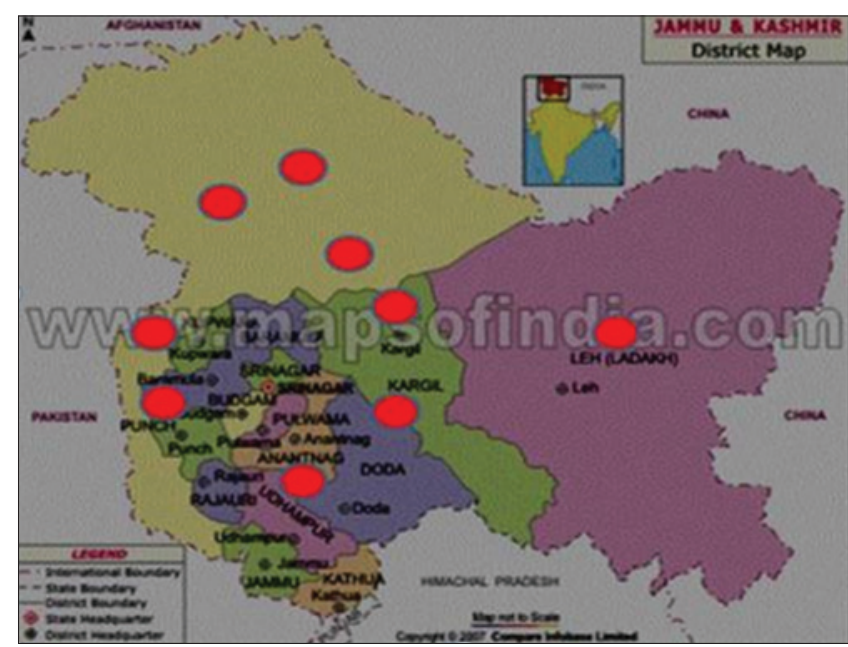

Figure 1: Map showing survey areas

Table 1: Information regarding the different localities of Kashmir visited during present studies

\begin{tabular}{|c|c|c|c|}
\hline $\begin{array}{l}\text { Species } \\
\text { (accession number) }\end{array}$ & Population & $\begin{array}{l}\text { Population } \\
\text { code }\end{array}$ & Altitude (m) \\
\hline R. emodi & Yousmarg & $\mathrm{DH}$ & 4267.2 \\
\hline PUP (59513)/KU & Sonamarg & SM & 3462.2 \\
\hline \multirow[t]{7}{*}{ (2010-KASH) } & Pahalgaam & DP & 3962.4 \\
\hline & Dodhpathri & GM & 3862.4 \\
\hline & Gulmarg & LR & 4476.8 \\
\hline & Tarsar Marsar & YM & 4657.2 \\
\hline & Dhara & TM & 3751.6 \\
\hline & Laar & $P G$ & 3657.6 \\
\hline & Tissue cultured plants & TC & \\
\hline \multirow[t]{2}{*}{ R. webbianum } & Khardungla (Leh) & PK & 4921.5 \\
\hline & Tangsti (Leh) & TG & 4725.8 \\
\hline $\begin{array}{l}\text { PUP (59515)/KU } \\
(2011-K A S H)\end{array}$ & $\begin{array}{l}\text { Panzila Top } \\
\text { (Zanaskar) }\end{array}$ & $\mathrm{KH}$ & 4593.8 \\
\hline PUP (59514)/KU & Tangole (Zanaskar) & TS & 4266.1 \\
\hline \multirow[t]{2}{*}{ (2011-KASH) } & Parkhachik (Zanaskar) & PT & 3938.4 \\
\hline & Tissue cultured plants & $\mathrm{TC}$ & - \\
\hline R. spiciforme & Dawar hills & SM & 4419.6 \\
\hline PUP (59516)/KU & Chakwali & CW & 4684.8 \\
\hline \multirow[t]{5}{*}{ (2012-KASH) } & Dahi Nala & TB & 3810.0 \\
\hline & Satni Mountain & $\mathrm{DH}$ & 3962.4 \\
\hline & $\begin{array}{l}\text { Habba Khatoon } \\
\text { Mountain }\end{array}$ & DN & 4756.8 \\
\hline & Tragbal & $\mathrm{HM}$ & 3352.8 \\
\hline & Tissue cultured plants & & - \\
\hline
\end{tabular}

From the list of surveyed localities, it is clearly reflected that vast area presenting variety of vegetation types has been covered with altitude ranging from 3352.8 to $4921.5 \mathrm{~m}$. +++: Fast response, ++ : Moderate response, + : Slow response, $R$. emodi: Rheum emodi, $R$. webbianum: Rheum webbianum, $R$. spiciforme: Rheum spiciforme

nodes, and plant height. These parameters were studied for scoring data regarding morphological features of the plant species. The nodes are absent in the case of $R$. webbianum and $R$. spiciforme. Hence, this parameter was not studied in these two species.

\section{Survey and Collection}

Rheum species are perennial, stout herbs, distributed in the temperate and sub-tropical regions of Himalaya from 
Kashmir to Sikkim lying at an altitude of 2800-3800 m. For this study, three species, i.e., R. emodi, R. webbianum, and $R$. spiciforme were collected from different habitats of Kashmir Himalaya (Plates 1-3).

\section{Maintenance of Germplasm (Ex-situ) in Nursery}

For germplasm establishment, plants, seeds, roots and rhizomes collected from different altitudes were grown in the different beds in Nursery at University of Kashmir (Plate 4 - Figures 22-25).

\section{Response of Rheum Species in Nursery}

In nursery, good seed germination ability was observed in natural soil, different soil texture groups and under the influence of urea. Sand was also mixed in the soil. However, maximum germination was recorded in sandy soil treated with urea in the ratio of 1:2.

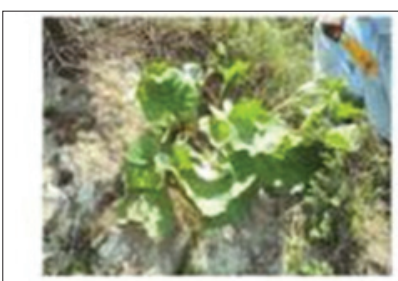

Fig.2:Dhara

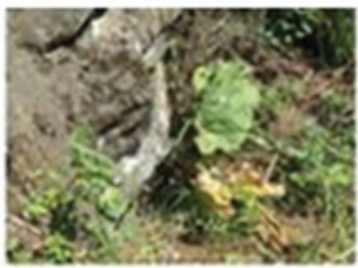

Fig.4: Pahalgaam

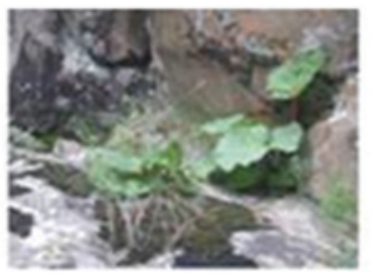

Fig.6: Tarsar Marsar

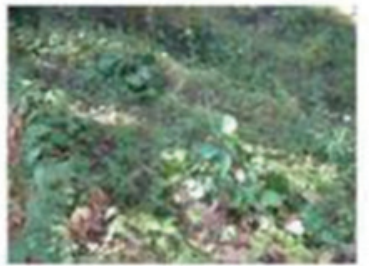

Fig.8: Dodhpathri

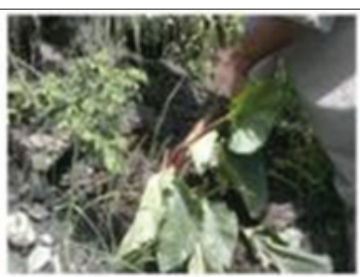

Fig.3:Yousmarg

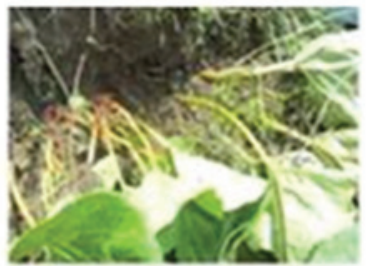

Fig.5: Sonmarg

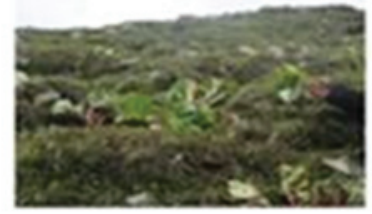

Fig.7: Gulmarg

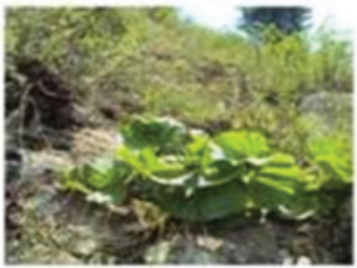

Fig.9: Laar
Plate 1: Rheum emodi collected from different altitudes of Kashmir Himalaya

\section{R. emodi}

The germplasm of R.emodi collected in 2010 showed rapid growth response in the nursery. The survival of the whole plants showed increment from 70\% to 90\% from 2011 to 2014 (Table 2, Plate 5 - Figures 26-28).

\section{R. webbianum}

The germplasm of $R$. webbianum showed slow growth response as compared to $R$. emodi in nursery. The survival rate during the year 2011-14 was 50-75\% (Table 2, Plate 5 - Figures 29-31).

\section{R. spiciforme}

The germplasm of R. spiciforme collected in 2011 also showed fast and good growth response and the survival rate observed in 3 years was $60-85 \%$ (Table 2, Plate 5 - Figures 32-34).

\section{Morphology of Rheum Species}

In this study, $R$. emodi, $R$. webbianum and $R$. spiciforme collected from different altitudes (natural habitats) were studied using different morphometric parameters (using standard techniques).

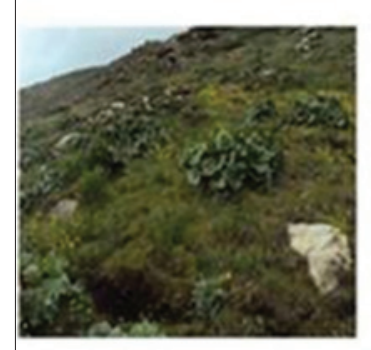

Fig.10: Panzila top

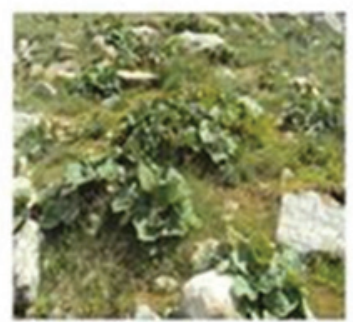

Fig.12: Tangole

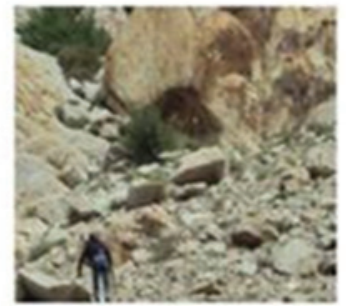

Fig.14: Khardungla

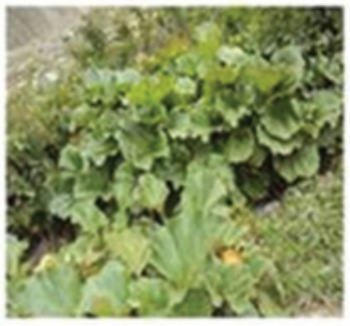

Fig.1l: Parkhachik

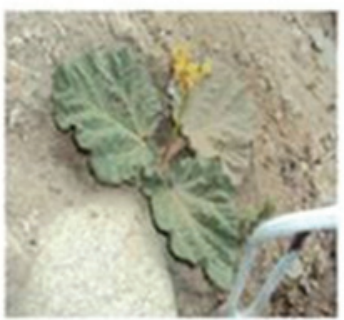

Fig.13: Tangsti

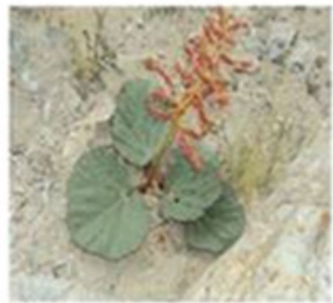

Fig.15: Plant of Khardungla

Plate 2: Rheum webbianum collected from different altitudes of Ladakh and Zanaskar valley 


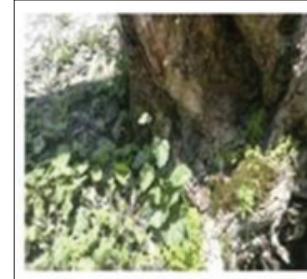

Fig.16:Dahi Nala

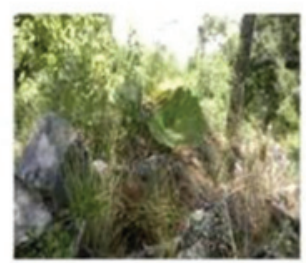

Fig.18: Satni Mountain

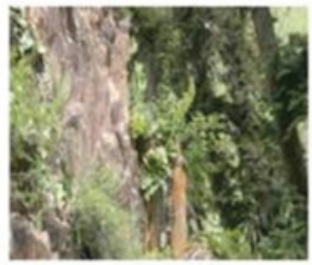

Fig. 20:Daw ar Hiils

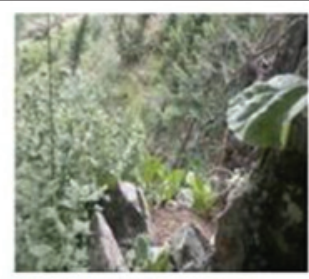

Fig.17: Chakw ali

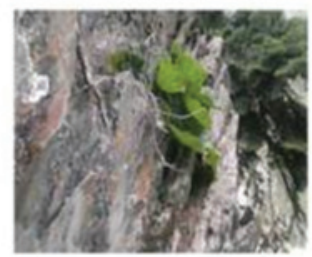

Fig.19: Habba Khatoon Mountains

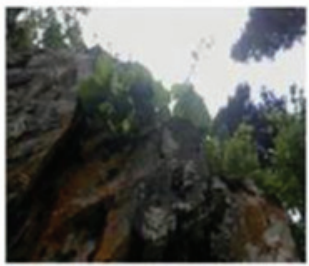

Fig.21: Tragbal
Plate 3: Rheum spiciforme collected from different altitudes of Gurez valley and nursery development

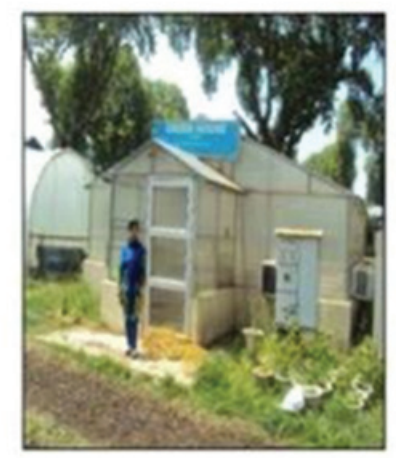

Fig.22

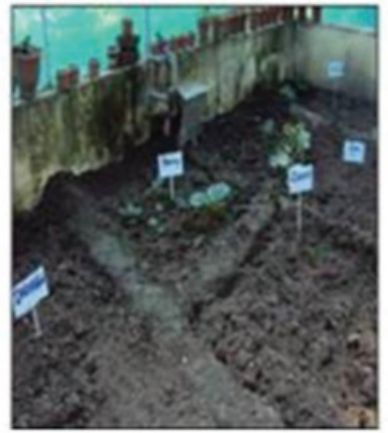

Fig. 24

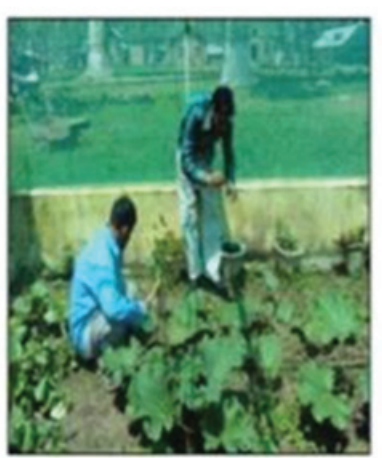

Fig. 23

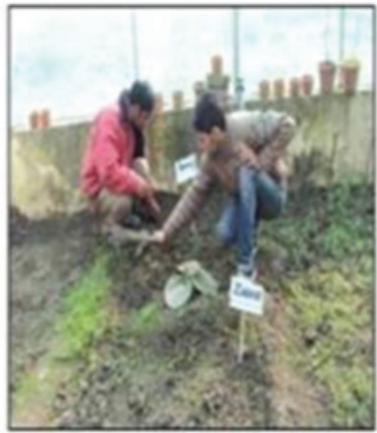

Fig. 25
Plate 4: Ex-situ conservation of Rheum species
Table 2: Ex-situ conservation of genetic diversity of Rheum species in net house

\begin{tabular}{lccccc}
\hline $\begin{array}{l}\text { Rheum species } \\
\text { (germplasm) }\end{array}$ & $\begin{array}{c}\text { Germination/ } \\
\text { growth response }\end{array}$ & \multicolumn{5}{c}{ Survival rate (\%) } \\
\cline { 3 - 6 } & & 2011 & 2012 & 2013 & 2014 \\
\hline R. emodi & + & 85 & 85 & 80 & 80 \\
$\quad$ Seeds & +++ & 70 & 85 & 90 & 90 \\
$\quad$ Whole plants & ++ & 60 & 70 & 80 & 80 \\
$\quad$ Roots and rhizomes & & & & & \\
$R$ R. webbianum & + & 60 & 60 & 55 & 50 \\
$\quad$ Seeds & +++ & 60 & 60 & 70 & 75 \\
$\quad$ Whole plants & ++ & 50 & 60 & 70 & 75 \\
$\quad$ Roots and rhizomes & & & & & \\
$R$. spiciforme & + & - & 80 & 75 & 75 \\
$\quad$ Seeds & +++ & - & 85 & 85 & 85 \\
$\quad$ Whole plants & ++ & - & 60 & 70 & 80 \\
Roots and rhizomes & & &
\end{tabular}

+++ : Fast response, ++ : Moderate response, + : Slow response,

R. emodi: Rheum emodi, R. webbianum: Rheum webbianum,

$R$. spiciforme: Rheum spiciforme

\section{R. emodi}

In the present studies, it was noticed that Rheum grows from both thick rhizomes and long roots. The maximum root, length, i.e., $67 \mathrm{~cm}$ and maximum shoot length, i.e., $52 \mathrm{~cm}$ were observed in Sonmarg plant and the maximum root thickness, i.e., $7.3 \mathrm{~cm}$ was found in Yousmarg plant as shown in plate 6. The maximum root area, i.e., $5.3 \mathrm{~cm}$ was also found in Yousmarg plant; the maximum leaf area, i.e., $22.7 \mathrm{~cm}$ was also found in Sonmarg plant. The maximum leaf length and leaf breadth, i.e., $46 \mathrm{~cm}$ and $54 \mathrm{~cm}$ was found in Gulmarg plant. The R. emodi of Laar in its natural habitat was found in large number in quadrants $7 / \mathrm{m}^{2}$. Fresh weight of root, i.e., $6 \mathrm{~g}$ was found in Sonamarg plant while as dry weight of root, i.e., $168 \mathrm{~g}$ was found in Dodhpathri plant. The maximum plant height in meters, i.e., $5.6 \mathrm{~m}$ was observed in Dodhpathri plant. Maximum number of branches, i.e., 19 and leaves, i.e., 28 were observed in Gulmarg plant. The maximum number of nodes, i.e. 10 was found in Laar plant (Tables 3 and 4).

\section{R. webbianum}

In the present studies, the maximum root length, i.e. $98 \mathrm{~cm}$ and thickness of root, i.e. $59 \mathrm{~cm}$ of $R$. webbianum were found in Tangsti plant. The maximum rhizome thickness, i.e. $68 \mathrm{~cm}$ of $R$. webbianum was found in Panzila Top and maximum rhizome length was found in Tangsti plant. The maximum leaf length, i.e. $34 \mathrm{~cm}$ and leaf breadth, i.e. $46 \mathrm{~cm}$ of $R$. webbianum were observed in Parkachik plant as shown in plate 6 . The maximum height, i.e. $1.4 \mathrm{~m}$ of $R$. webbianum was observed in Panzila Top plant. The maximum number of branches, i.e. 14 and leaves, i.e. 18 of R. webbianum were found in Parkachik plant. The R. webbianum found in Parkachik area was more in number, i.e. $17 / \mathrm{m}^{2}$ 


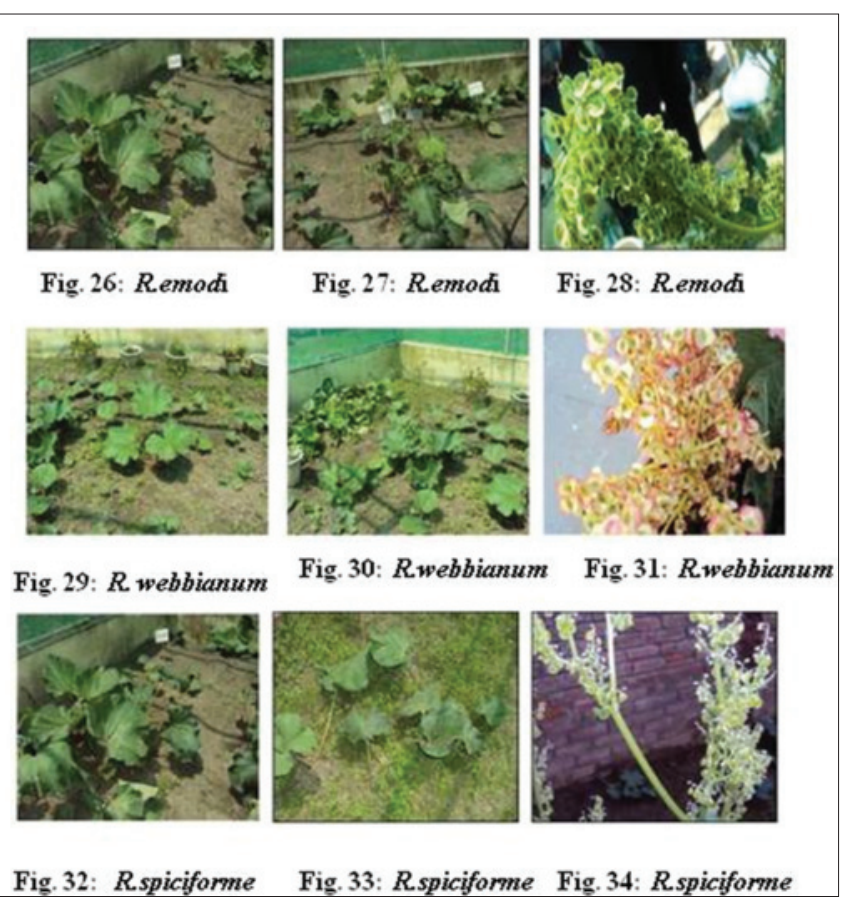

Plate 5: Roots of Rheum species collected from different localities

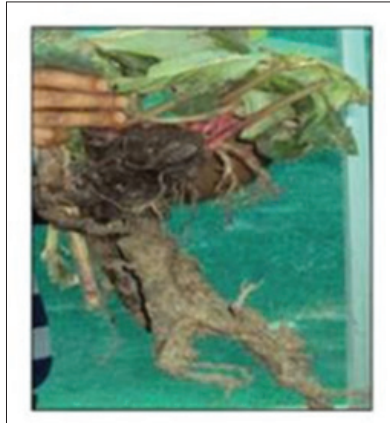

Fig. 35: R.emodi

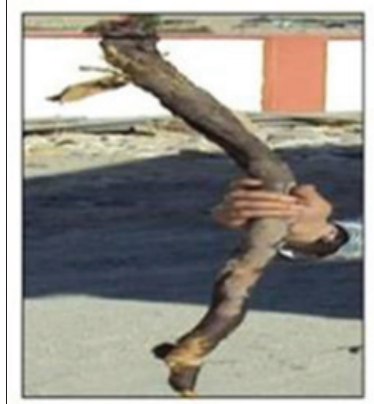

Fig. 37: R.webbianum

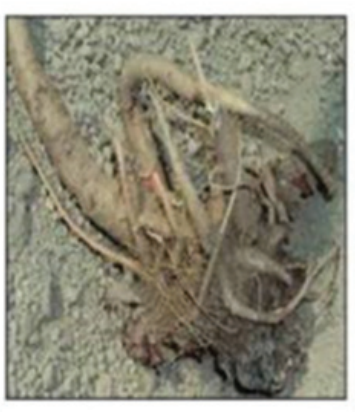

Fig. 36: R.emodi

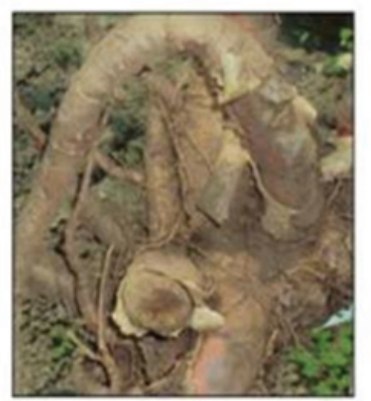

Fig. 38: R.spiciforme

Plate 6 : Roots of different species of Rhenm

Plate 6: Roots of different species of Rheum

(Tables 5 and 6).

\section{R. spiciforme}

In present studies, the maximum root length, i.e. $64 \mathrm{~cm}$

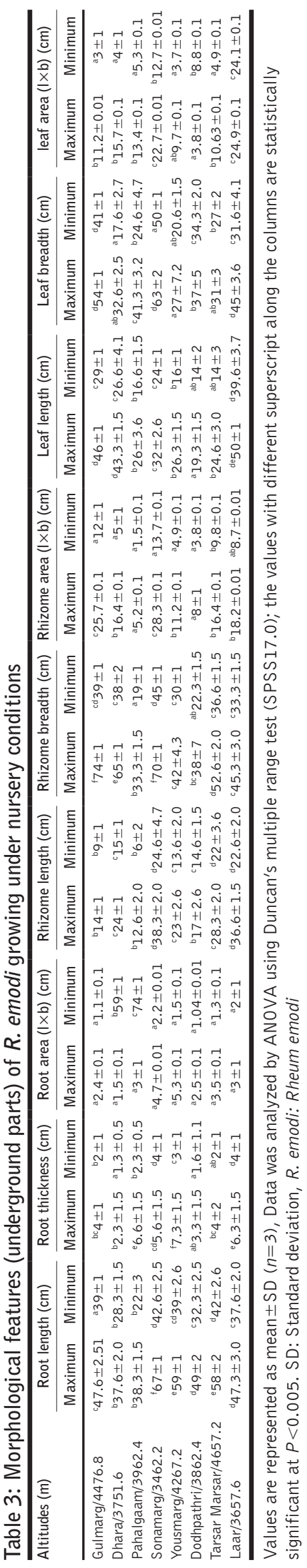

Current Botany 


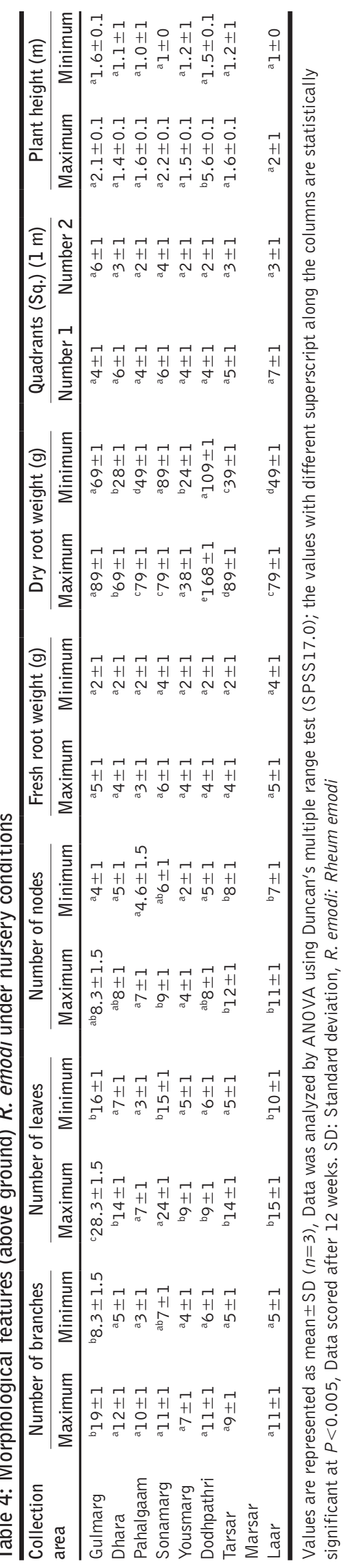

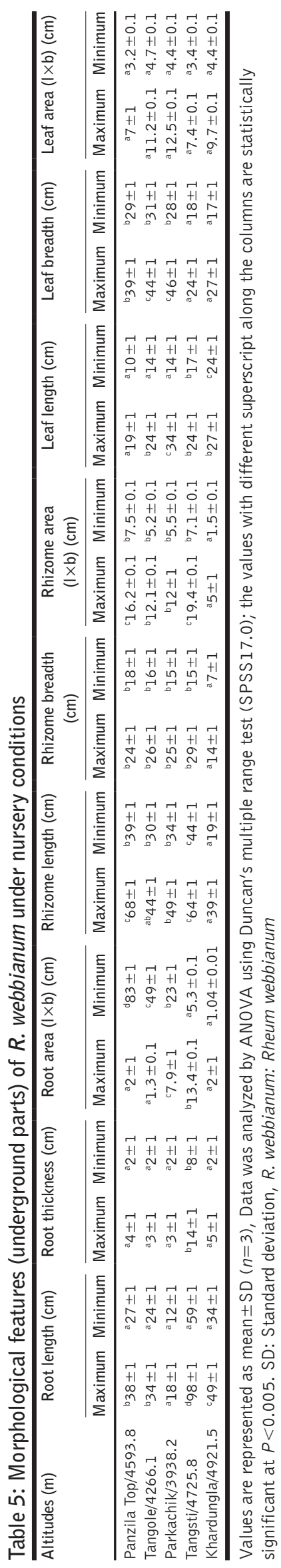

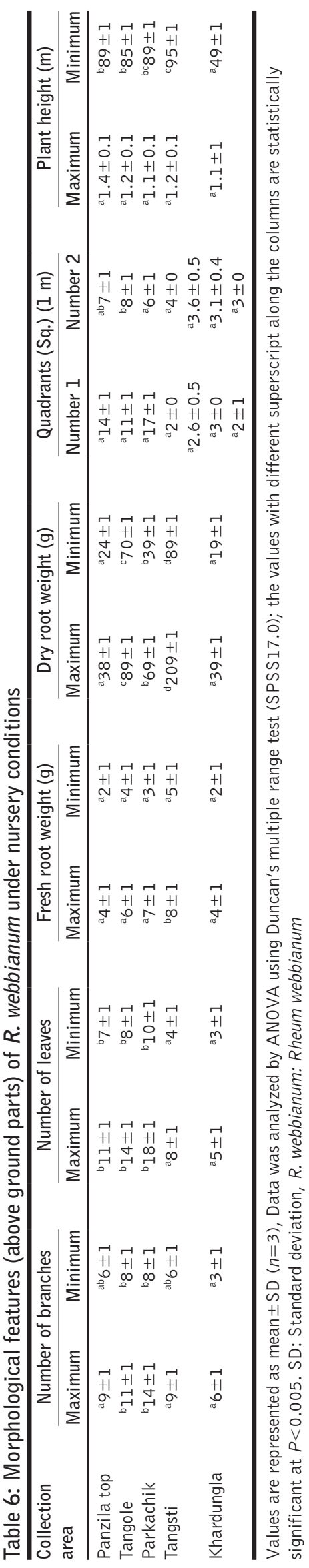


and thickness, i.e. $8 \mathrm{~cm}$ of $R$. spiciforme were found in Chakwali plant. The maximum rhizome length, i.e. $79 \mathrm{~cm}$ and thickness, i.e. $59 \mathrm{~cm}$ of R. spiciforme were also found in Chakwali plant. The maximum leaf length, i.e. $54 \mathrm{~cm}$ and breadth, i.e. $59 \mathrm{~cm}$ of $R$. spiciforme were also found in Chakwali plant as shown in plate 6. The maximum plant height, i.e. $2 \mathrm{~m}$ was also found in Chakwali plant. The maximum fresh, i.e. $14 \mathrm{~g}$ and dry root weight, i.e. $149 \mathrm{~g}$ were found in Tragbal area. The R. spiciforme in its natural habitat in Chakwali was found higher in number, i.e. $14 / \mathrm{m}^{2}$. The maximum number of branches, i.e. 14 and leaves, i.e. 18 was found in Habba Khatoon Mountain area (Tables 7 and 8 ).

\section{DISCUSSION}

Morphological features are important in classifying the genotypes into different groups and records of these traits in different populations give the estimate of the range of these traits found in a species. Further, many of the morphological features may have a positive correlation with the synthesis and production of any phytocontituent/ phytochemical of the plant. Thus, study of morphology becomes more important as it can indicate the best genotypes in relation to some active principles found in plants. Therefore, in this study, we recorded at least nine morphological features in all the three species of Rheum. These three species of Rheum (R. emodi, R. webbianum, and R. spiciforme) were collected, i.e. from different altitudes of Kashmir Himalaya and studied using different morphometric parameters (using standard techniques). R. emodi is a perennial plant that grows from thick and erected rhizomes and as well as from long roots. The leaves are large, triangular and broadly ovate with fleshy petioles. The flowers are small, greenish-white on large compound leafy inflorescences. Nodes are also present. $R$. webbianum is also having basal and cauline leaves. Basal leaves are orbicular or broadly ovate and are triangular in shape with long, fleshy petioles. Flowers are reddish pink in color. Nodes are absent in this species. R. spiciforme is also stout herb. Leaves are also broadly ovate and triangular in shape. It has also thick rhizomes and long roots. Flowers are small and yellowish green. Nodes are absent in this species. These species were grown in net house (Kashmir University) under suitable conditions as they have been listed under endangered category and are under threat. Rheum species are one of the known medicinal plants. Rheum has been vanished from lower localities, and now are found only on higher altitudes.

In net house, all the three Rheum species showed good response and survival rate was also good but $R$. emodi

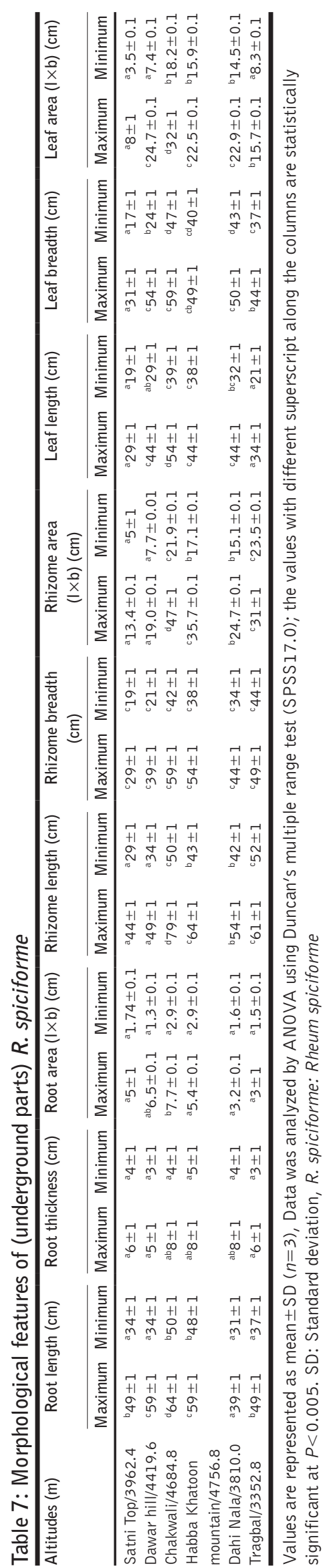

Current Botany • Vol 7 • 2016 
Table 8: Morphological features (above ground parts) of $R$. spiciforme

\begin{tabular}{|c|c|c|c|c|c|c|c|c|c|c|c|c|}
\hline \multirow[t]{2}{*}{ Collection area } & \multicolumn{2}{|c|}{ Number of branches } & \multicolumn{2}{|c|}{ Number of leaves } & \multicolumn{2}{|c|}{ Fresh root weight (g) } & \multicolumn{2}{|c|}{ Dry root weight (g) } & \multicolumn{2}{|c|}{ Quadrants (Sq.) (1 m) } & \multicolumn{2}{|c|}{ Plant height (m) } \\
\hline & Maximum & Minimum & Maximum & Minimum & Maximum & Minimum & Maximum & Minimum & Number 1 & Number 2 & Maximum & Minimum \\
\hline Satni top & ${ }^{\mathrm{a}} 10 \pm 1$ & $a b 7 \pm 1$ & ${ }^{a} 5 \pm 1$ & ${ }^{a} 3 \pm 1$ & ${ }^{a} 7 \pm 1$ & $a_{3} \pm 1$ & bc90 91 & ab $79 \pm 1$ & ${ }^{a} 7 \pm 1$ & ${ }^{a} 3 \pm 1$ & ${ }^{\mathrm{a}} 1.6 \pm 0.1$ & ${ }^{\mathrm{a}} 1.1 \pm 0.1$ \\
\hline Dawar hill & $\mathrm{a} 9 \pm 1$ & ${ }^{a} 6 \pm 1$ & ${ }^{\mathrm{ab}} 11 \pm 1$ & $a 7 \pm 1$ & ${ }^{\mathrm{a}} 6 \pm 1$ & ${ }^{\mathrm{a}} 2 \pm 1$ & a79 \pm 1 & $a b 70 \pm 1$ & $\mathrm{a} 9 \pm 1$ & ab $7 \pm 1$ & ${ }^{\mathrm{a}} 1.7 \pm 0.1$ & ${ }^{\mathrm{a}} 1.2 \pm 0.1$ \\
\hline Chakwali & ${ }^{\mathrm{a}} 11 \pm 1$ & ${ }^{b} 8 \pm 1$ & ${ }^{b} 14 \pm 1$ & ${ }^{a b} 8 \pm 1$ & ${ }^{\mathrm{a}} 9 \pm 1$ & ${ }^{a} 4 \pm 1$ & c95 951 & ${ }^{\mathrm{b}} 78 \pm 1$ & ${ }^{\mathrm{b}} 14 \pm 1$ & ${ }^{b} 9 \pm 1$ & a $2.1 \pm 0.1$ & ${ }^{\mathrm{a}} 1.9 \pm 0.1$ \\
\hline $\begin{array}{l}\text { Habba Khatoon } \\
\text { mountain }\end{array}$ & ab $14 \pm 1$ & ${ }^{\mathrm{a}} 8 \pm 1$ & ${ }^{\mathrm{b}} 18 \pm 1$ & ${ }^{\mathrm{b}} 10 \pm 1$ & ${ }^{\mathrm{a}} 8 \pm 1$ & $a 5 \pm 1$ & b89 81 & ${ }^{\mathrm{a}} 67 \pm 1$ & ${ }^{\mathrm{a}} 8 \pm 1$ & $a 4 \pm 1$ & a $2.0 \pm 0.1$ & ${ }^{\mathrm{a}} 1.8 \pm 0.1$ \\
\hline Dahi Nala & a $9 \pm 1$ & ${ }^{\mathrm{a}} 4 \pm 1$ & a $7 \pm 1$ & $a_{3} \pm 1$ & ${ }^{a b} 10 \pm 1$ & ${ }^{a b} 7 \pm 1$ & $98 \pm 1$ & ${ }^{8} 89 \pm 1$ & ${ }^{\mathrm{a}} 9 \pm 1$ & ${ }^{a b} 7 \pm 1$ & ${ }^{\mathrm{a}} 1.7 \pm 0.1$ & ${ }^{\mathrm{a}} 1.3 \pm 0.1$ \\
\hline Tragbal & a $7 \pm 1$ & $a 3 \pm 1$ & ${ }^{2} 6 \pm 1$ & $a+1$ & ${ }^{b} 14 \pm 1$ & ${ }^{b} 8 \pm 1$ & ${ }^{d} 149 \pm 1$ & d $99 \pm 1$ & ${ }^{a} 7 \pm 1$ & ${ }^{2} 5 \pm 1$ & a $1.8 \pm 0.1$ & ${ }^{\mathrm{a}} 1.6 \pm 0.1$ \\
\hline
\end{tabular}

Values are represented as mean \pm SD $(n=3)$, Data was analyzed by ANOVA using Duncan's multiple range test (SPSS17.0); the values with different superscript along the columns are statistically significant at $P<0.005$. SD: Standard deviation, $R$. spiciforme: Rheum spiciforme

and $R$. spiciforme showed good survival rate as compared to $R$. webbianum. The species of Rheum, i.e. R. nobile and R. alxandrae possesses large bracts and these bracts have been found to protect reproductive organs from damage by the high levels of UV-B radiations associated with the high altitudes of the plateau (Terashima et al., 1993; Omori and Ohba, 1996; Omori et al., 2000). This type of bract also occurs in other alpine plants, e.g., Sassurea of Asteraceae (Wang and Liu 2004).

The ex-situ germplasm of $R$. emodi showed rapid and fast growth response. The germplasm of $R$. webbianum showed slow growth response in net house. The germplasm of $R$. spiciforme also showed fast and good growth response. During survey, 10 morphological features of R. emodi were observed. Of these, maximum root length, i.e., $67 \mathrm{~cm}$ was observed in Sonamarg population while minimum root length, i.e. $37.6 \mathrm{~cm}$ was observed in Dhara plant. The maximum root thickness, i.e. $7.3 \mathrm{~cm}$ was found in Yousmarg plant. The maximum leaf length and leaf breadth, i.e. $46 \mathrm{~cm}$ and $54 \mathrm{~cm}$, respectively, were found in Gulmarg plant. The maximum plant height $(5.6 \mathrm{~m})$ was observed in Dodhpathri plant.

In the case of $R$. webbianum, the maximum rhizome thickness, i.e. $68 \mathrm{~cm}$ was found in Panzila Top and maximum rhizome length was found in Tangsti plant. The maximum leaf length, i.e. $34 \mathrm{~cm}$ and leaf breadth, i.e. $46 \mathrm{~cm}$ were observed in Parkhachik plant. The maximum height, i.e. $1.4 \mathrm{~m}$ was observed in Panzila Top plant. The maximum number of branches, i.e. 14 and leaves, i.e. 18 of $R$. webbianum were found in Parkhachik plant. Likewise, in R. spiciforme the maximum root length, i.e. $64 \mathrm{~cm}$ and thickness, i.e. $8 \mathrm{~cm}$ were found in Chakwali plant. The maximum rhizome length, i.e. $79 \mathrm{~cm}$ and thickness, i.e. $59 \mathrm{~cm}$ of $R$. spiciforme were also found in Chakwali plant. The maximum leaf length, i.e. $54 \mathrm{~cm}$ and breadth, i.e. $59 \mathrm{~cm}$ were also found in Chakwali plant. The maximum plant height, i.e. $2 \mathrm{~m}$ was also found in Chakwali plant.
When all the three species taken into account, R. emodi exhibited maximum diversity in six (rhizome breadth, leaf length, leaf breadth, no. of branches, no. of leaves, and plant height) morphological traits while $R$. webbianum showed maximum diversity in two (root length and root thickness) morphological traits and $R$. spiciforme showed maximum diversity in one (rhizome length) morphological trait. As it is well-known fact that phenotypic traits are influenced by environmental conditions, the diversity detected in specific traits in all these species may be attributed to the climatic conditions prevailing in habitats of each species. Further, when mean altitudinal collections analyzed we found that $R$. webbianum showed its occurrence in higher altitudes than other two species, and we also found that roots of this species were showing greater diversity as compared to other two species which may be the result of its adaptive behavior toward alpine region and higher endurance toward harsh cold temperature. Likewise, the diversity in branches, leaves and plant height in the case of $R$. emodii can be attributed to suitable and nutrient rich environment of low altitude as compared to R. webbianum. All these morphological traits in addition to others are required to study with larger sampling and covering diverse populations so that some standard descriptor can be developed to identify elite germplasm from the natural strands of Rheum species.

Rheum species contains anthraquinone derivatives, anthrones and tannins, etc., in which anthraquinone derivatives including emodin, aloe-emodin, rhein, physcion, chrysophanol and their glucosides are the accepted important active components. Aloe-emodin is a natural active compound present in the Rheum species. It has also been found that aloe-emodin has numerous biological properties including antiviral, antimicrobial, and hepatoprotective activities. Aloeemodin has been reported to exhibit anticancer activity on neuroectodermal tumors, lung squamous cell carcinoma, and hepatoma cells. Another compounds found in Rheum 
species are emodin, rhein, chrysaphanol, physicion, etc., and therefore, conservation of Rheum species is very important as this plant is under great threat and listed as endangered plant.

\section{CONCLUSION}

The Rheum species, i.e. R. emodi, R. webbianum and $R$. spiciforme are identified on the basis of main features, i.e. R. emodi is having nodes whereas nodes are absent in $R$. webbianum and $R$. spiciforme. The flowers of $R$. webbianum are reddish pink whereas the flowers of $R$. emodi are greenish white and flowers of $R$. spiciforme are yellowish green. The R. emodi and $R$. spicifome are cliff hangers, they are mostly found in rocky areas, whereas $R$. webbianum is found mostly on plain slopes of hills and they are short herbs. The collected germplasm was grown in net house of Kashmir University and at least nine quantitative traits were recorded in all the three species. Of the nine traits studied, R. emodi exhibited maximum diversity in six (rhizome breadth, leaf length, leaf breadth, number of branches, no. of leaves, and plant height) morphological traits while $R$. webbianum showed maximum diversity in two (root length and root thickness) traits and $R$. spiciforme showed maximum diversity in one (rhizome length) morphological trait. The diversity detected in studied traits in all these species may be attributed to adaptive behavior of each species toward the climatic conditions prevailing in habitats of each species.

The conservation of Rheum species is very necessary as they are one of the most important medicinal plants. Rheum species contains anthraquinone derivatives, anthrones and tannins, etc., in which anthraquinone derivatives including emodin, aloe-emodin, rhein, physcion, chrysophanol, and their glucosides are the accepted important active components. Aloe-emodin is a natural active compound present in the Rheum species. It has also been found that aloe-emodin has numerous biological properties including antiviral, antimicrobial and hepatoprotective activities. Aloe-emodin has been reported to exhibit anticancer activity on neuroectodermal tumors, lung squamous cell carcinoma, and hepatoma cells. Another compounds found in Rheum species are emodin, rhein, chrysaphanol, physicion, etc. The Rheum species are also used by tribal and local people for many diseases such as, wounds and boils, Jaundice, cough and asthma muscular pain/body ache freckle/skin eruptions/skin diseases swelling, inflammation/rheumatic pain, constipation piles bone fracture/backache/joint pain rheumatic pain stomachache/intestinal infections/and dysentery. Its leaves are taken as Food.

\section{ACKNOWLEDGMENT}

This study was supported by DST, GoI, New Delhi funded women entrepreneurship project, the assistance of which is highly acknowledged. We are also highly thankful to DBT (IPLS) for their help and support by giving funds for present studies.

\section{REFERENCES}

Constabel F. Medicinal plant biotechnology. Planta Med 1990;56:421-5.

Ensminger AH, Ensminger ME, Konlande JE, Robson JR. Food \& Nutrition Encyclopedia. Vol. 2. Clovis, California, USA: Pegus Press; 1983. p. 1427-41.

Agarwal SK, Singh SS, LakshmiV, Verma S, Kumar S. Chemistry and pharmacology of rhubarb (Rheum species) - A review. J Sci Ind Res 2001;60:1-9.

Nautiyal BP, Prakash V, Maithani UC, Chauhan RS, Purohit H, Nautiyal MC. Germinability, productivity and economic viability of Rheum emodi WALL. Ex Meissn. Cultivated at lower altitude. Curr Sci 2003;84:143-8.

Chaurasia OP, Ahmed Z, Ballabh B. Ethnobotany and Plant of Trans-Himalaya. New Delhi, India: Satish Serial Publishing House; 2007. p. 1-544.

Shimomura K, Yoshimatsu K, Jaziri M, Ishimaru K. Traditional medicinal plant genetic resources and biotechnology applications. In: Watanabe K, Pehu ER, editors. Plant Biotechnology and Plant Genetic Resources for Sustainability and Productivity. Austin, Texas: R. G. Landes Company and Academic Press Inc.; 1997. p. 209-25.

Shu DH, Bojian B, Grabovskaya-Borodina AE. Flora of China. Vol. 5. Beijing: Science Press; 2003. p. 341-50.

Terashima I, MasuzawaT, Ohba H. Photosynthetic characteristics of a giant alpine plant, Rheum nobile Hook. F. Et Thoms. and of some other alpine species measured at $4300 \mathrm{~m}$, in the Eastern Himalaya, Nepal. Oecologia 1993;95:194-201.

OmoriY, Ohba H. Pollen development of Rheum nobile Hook. F. \& Thomson (Polygonaceae), with reference to its sterility induced by bract removal. Bot J Linn Soc 1996;122:269-78.

OmoriY, Takayama H, Ohba H. Selective light transmittance of translucent bracts in the Himalayan giant glasshouse plant Rheum nobile Hook. F. \& Thomson (Polygonaceae). Bot J Linn Soc 2000;132:19-27.

WangYJ, Liu JQ. A preliminary investigation on the phylogeny of Saussurea (Asteraceae: Cardueae) based on chloroplast DNA trnL-F sequences. Acta Phytotaxonom Sin 2004;42:136-53. 